\title{
Discrimination of methicillin-resistant Staphylococcus aureus from borderline-resistant and susceptible isolates by different methods
}

\author{
C. A. RESENDE and A. M. S. FIGUEIREDO \\ Universidade Federal do Rio de Janeiro, Instituto de Microbiologia, Laboratório de Biologia Molecular de \\ Bactérias, Cidade Universitária, CCS Bloco I, Rio de Janeiro, RJ, Brazil 21941.590
}

\begin{abstract}
Methicillin-resistant Staphylococcus aureus (MRSA) are important nosocomial pathogens. Diseases caused by these resistant bacteria frequently are serious and there is a need to control the spread of epidemic MRSA clones in hospitals. However, detection is complicated by the fact that expression of the resistance is variable and, commonly, heterogeneous within strains. The reliability of several tests recommended to discriminate heterogeneous MRSA isolates from borderline-resistant and susceptible strains was evaluated. Screening for growth on agar with methicillin $25 \mathrm{mg} / \mathrm{L}$ was the only method that detected all MRSA strains tested, but screening on agar with methicillin $10 \mathrm{mg} / \mathrm{L}$ or oxacillin $6 \mathrm{mg} / \mathrm{L}$ detected all but one of 10 heterogeneously resistant strains tested. None of the borderline-resistant nor any truly susceptible staphylococei tested grew on any of these screening plates.
\end{abstract}

\section{Introduction}

Methicillin was the first $\beta$-lactamase-stable $\beta$-lactam antibiotic described and overcame resistance caused by staphylococcal penicillinase. Subsequently, however, methicillin-resistant Staphylococcus aureus (MRSA) strains have emerged worldwide as major causes of hospital infections [1-4]. The determinant of methicillin resistance is the mecA gene, which encodes penicillin-binding protein $2 \mathrm{a}\left(2^{\prime}\right)$, a component that is not present in methicillin-susceptible or borderlineresistant strains $[5,6]$. This $78-\mathrm{kDa}$ membrane protein has low affinity for $\beta$-lactam antibiotics [7]. Although $m e c A$ has been detected in all MRSA so far tested, there is enormous variation in the phenotypic expression of methicillin resistance, with many strains showing heterogeneous resistance [8]. Several auxiliary genes $[9,10]$ seem to be involved in determining the heterogeneous phenotype.

MRSA isolates can be divided into four phenotypic classes by population analysis profile [11]. These profiles are stable in vitro [11,12] and in vivo [13]. For 'Class 1' heterogeneous strains the MICs for most cells $($ c. $99 \%)$ are low $(1.5-3.0 \mathrm{mg} / \mathrm{L})$ and only a small sub-population $\left(10^{-8}-10^{-6}\right)$ is highly resistant.

Received 9 Jan. 1996; revised version accepted 26 June 1996.

Corresponding author: Professor A. M. S. Figueiredo.
In 'Class 2' heterogeneous MRSA, the MIC values for the majority of cells are higher $(6-25 \mathrm{mg} / \mathrm{L})$ and the highly resistant sub-population comprises a larger fraction $\left(10^{-5}-10^{-4}\right)$ of the total. MICs for Class 3 strains typically exceed $50 \mathrm{mg} / \mathrm{L}$ and the proportion of highly resistant cells is increased to $10^{-3}-10^{-1}$. The least frequent class of MRSA - Class 4 - comprises strains with homogeneous resistance. MIC values for these organisms exceed $400 \mathrm{mg} / \mathrm{L}$ [12].

These complex phenotypes complicate the detection of resistance: in the Class 1 phenotype, methicillin MICs for most cells may be as low as $1.5 \mathrm{mg} / \mathrm{L}$, compared to $0.5-1.0 \mathrm{mg} / \mathrm{L}$ for truly susceptible $S$. aureus [14]. MICs as high as those for the majority of cells in the class 1 phenotype are also seen for some 'borderlineresistant' $S$. aureus strains that lack the mecA gene $[14,15]$ and which may hyperproduce $\beta$-lactamase or have reduced penicillin affinity for both PBPs 1 and 2, coupled to overproduction of PBP 4 [15].

Earlier studies showed that MRSA Classes 1 and 2 could hardly be discriminated from borderline-resistant strains by disk diffusion tests [14]. Other studies [1618] have compared different methods - including screening for growth on methicillin-containing agar to detect MRSA strains, but did not consider the phenotypic variability among heterogeneous MRSA.

This study examined whether heterogeneous MRSA 
and borderline-resistant $S$. aureus strains could be discriminated from the truly susceptible strains by any recommended test.

\section{Materials and methods}

\section{Isolates}

Ninety-nine Staphylococcus aureus clinical isolates from our collection were used, and were from various hospitals in Brazil. S. aureus ATCC 25923 was used as the control organism in disk diffusion and broth macrodilution tests.

For preparation of stock cultures, clinical isolates from agar slants were plated on to trypticase soy agar (TSA) to confirm purity. One isolated colony was then grown to the stationary phase in trypticase soy broth (TSB) and stored at $-70^{\circ} \mathrm{C}$ with sterile glycerol $10 \%$ $\mathrm{v} / \mathrm{v}, \quad S$, aureus strains representing each class of methicillin heteroresistance were obtained from $\mathrm{Dr}$ A. Tomasz.

Methicillin resistance was confirmed with a DNA probe comprising a Pst I-XbaI internal fragment of the mecA gene cloned in pTZ219 [14].

\section{Population analysis profile (PAP)}

Overnight cultures $\left(10^{9}-10^{10} \mathrm{cfu} / \mathrm{ml}\right)$ were plated at different dilutions on TSA containing serial two-fold dilutions of methicillin at concentrations of 0 and $0.75-800 \mathrm{mg} / \mathrm{L}$. Colonies were counted after incubation at $37^{\circ} \mathrm{C}$ for $48 \mathrm{~h}[13]$.

\section{Disk diffusion susceptibility tests}

Disk diffusion tests were carried out as recommended by the National Committee for Clinical Laboratory Standards (NCCLS) [19]. The bacterial inoculum, $\left(5 \times 10^{7}\right)-\left(9 \times 10^{7}\right) \mathrm{cfu} / \mathrm{ml}$, was plated on to Müeller-Hinton agar (MHA), and disks containing oxacillin (Cecon, São Paulo, Brazil) $1 \mu \mathrm{g}$ were applied. The plates were examined after incubation at $35^{\circ} \mathrm{C}$ for $24 \mathrm{~h}$ [19].

\section{Broth macrodilution}

Broth macrodilution susceptibility tests were performed in Müeller-Hinton broth according to the NCCLS guidelines [20]. Oxacillin was tested at final concentrations from 0.25 to $32 \mathrm{mg} / \mathrm{L}$ and with $\mathrm{NaCl} 2 \% \mathrm{w} / \mathrm{v}$ added to the broth. Incubation was at $35^{\circ} \mathrm{C}$ for $24 \mathrm{~h}$.

\section{Oxacillin and methicillin screening agars}

MHA was supplemented with oxacillin $6 \mathrm{mg} / \mathrm{L}$ or methicillin $10 \mathrm{mg} / \mathrm{L}$ and $\mathrm{NaCl} \mathrm{4 \%} \mathrm{w/v.} \mathrm{The} \mathrm{inoculum}$ was prepared in two ways: either (i) as recommended by NCCLS guidelines [19], giving $10^{7} \mathrm{cfu} /$ plate or (ii) as suggested by Kloos and Jorgensen, giving $10^{4} \mathrm{cfu} /$ plate [21]. The plates were incubated at $35^{\circ} \mathrm{C}$ for $24 \mathrm{~h}$.

\section{Methicillin agar screen}

Fifty $\mu \mathrm{l}$ of the frozen stock culture were inoculated into $2 \mathrm{ml}$ of TSB and incubated at $37^{\circ} \mathrm{C}$ in a shaking device that ensured vigorous aeration and a high bacterial concentration $\left(c .10^{9}-10^{10} \mathrm{cfu} / \mathrm{ml}\right)$. Portions of these cultures $(100 \mu \mathrm{l})$ were then plated on to TSA plates containing methicillin $25 \mathrm{mg} / \mathrm{L}$. Methicillin resistance was confirmed by surface growth after incubation for $24-48 \mathrm{~h}$ at $37^{\circ} \mathrm{C}[14]$.

\section{Results}

\section{Population analysis profiles of MRSA isolates}

By comparison with the controls the clinical $S$. aureus isolates were grouped into truly susceptible isolates, borderline-resistant and MRSA heterogeneous Classes 1, 2 or 3 (Fig. 1). Class 3 MRSA isolates were the most frequent phenotype (28\%); as Classes 1 and 2 MRSA isolates represented $9 \%$ and $4 \%$ of the total, respectively; whereas borderline-resistant isolates (MIC 2$4 \mathrm{mg} / \mathrm{L}$ ) comprised $44 \%$ and truly susceptible $S$. aureus (MIC $\leqslant 1 \mathrm{mg} / \mathrm{L}$ ) $14 \%$ (Fig. 2). No homogeneous (Class 4) MRSA were isolated.

\section{Detection of MRSA by recommended methods}

Three $(7 \%)$ of the MRSA isolates were not identified reliably by disk diffusion tests, giving zones larger than $10 \mathrm{~mm}$, whereas $20 \%$ of borderline-resistant isolates gave zones $\leqslant 10 \mathrm{~mm}$ in diameter (Table 1). Only MRSA from Class 3 and some heterogeneous Class 2 isolates were reliably identified as resistant by disk diffusion tests. All Class 3 isolates grew to the disk edge without halo formation (Table 1). Inhibition zones for borderline-resistant isolates ranged from $19 \mathrm{~mm}$ to $8 \mathrm{~mm}$, and a similar range of zone diameters (17$8 \mathrm{~mm}$ ) was observed for Class 1 MRSA and some Class 2 isolates (Table 1). When broth macrodilution tests with $\mathrm{NaCl} 2 \% \mathrm{w} / \mathrm{v}$ were used, two of six Class 1 and 2 MRSA isolates were erroneously classified as susceptible, with MICs of $4 \mathrm{mg} / \mathrm{L}$ being observed.

Screening tests with agar containing methicillin $10 \mathrm{mg} / \mathrm{L}$ and oxacillin $6 \mathrm{mg} / \mathrm{L}$ have also been advocated to discriminate Class 1 and 2 MRSA from borderline isolates $[19,21]$. However, one Class 1 MRSA failed to grow on these media when the inoculum was prepared as recommended by NCCLS [19] (i.e. with c. $10^{7}-10^{6} \mathrm{cfu} /$ plate) and only two Class 1 and 2 isolates grew when an inoculum of $10^{4} \mathrm{cfu} /$ plate was used, as suggested by Kloos and Jorgensen (Table 2) [21]. The screening plate with methicillin $25 \mathrm{mg} / \mathrm{L}$ was the only method that detected all MRSA isolates tested. None of the borderline- 


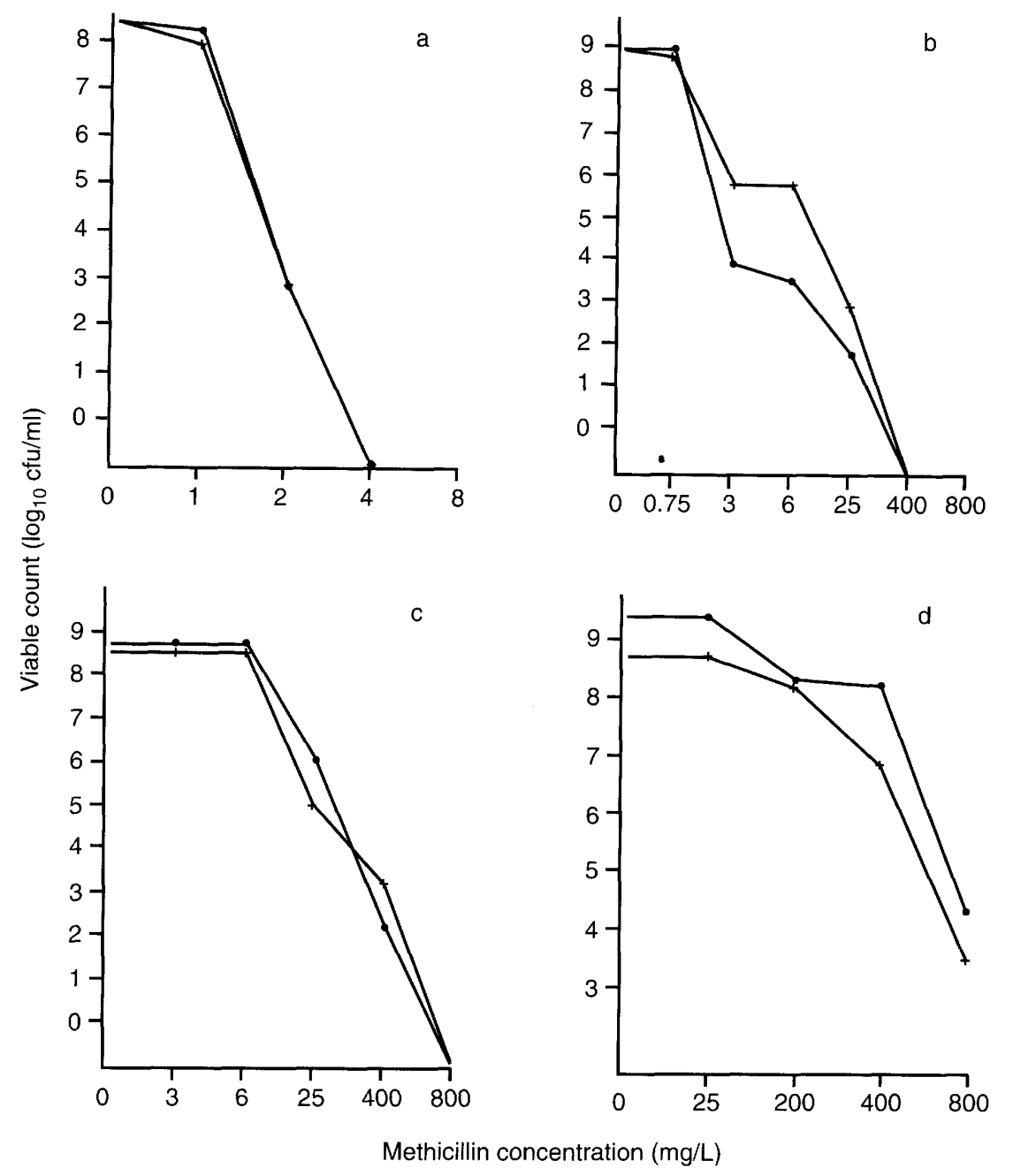

Fig. 1. Population analysis profiles of representative strains. a, borderline-resistant strains; b, MRSA Class 1; c, MRSA Class 2; d, MRSA Class 3.

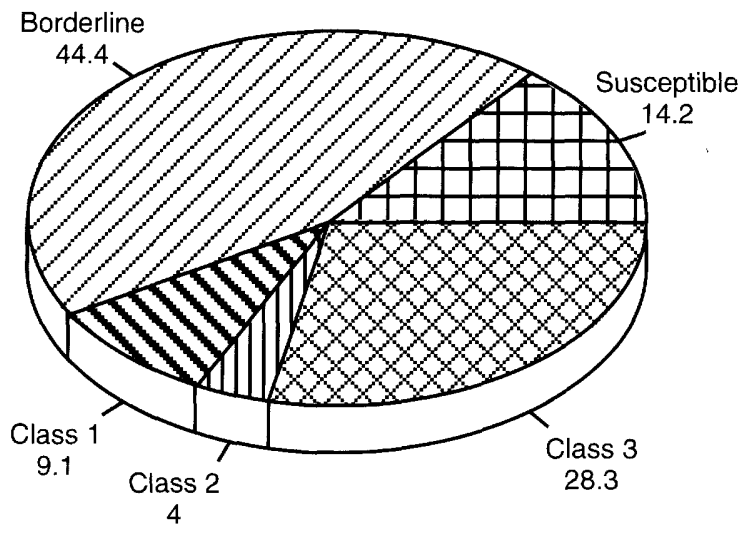

Fig. 2. Percentages of methicillin susceptible, borderline and resistant isolates among the $S$. aureus isolates studied.

resistant nor truly susceptible staphylococci tested grew on any of the screening media.

\section{Discussion}

Staphylococci are still the most common agents of hospital infections [1] and the emergence of MRSA has led to increased use of expensive and potentially toxic antibiotics. Infections caused by MRSA are often serious, even life-threatening. Thus there is a need to invest in control measures to prevent transmission of MRSA in hospitals [22], and this demands reliable techniques to discriminate these organisms from other staphylococci. DNA probes for mecA allow accurate and rapid detection of MRSA $[14,16]$, but the methodology needs to be made less expensive and simpler if it is to be used routinely in clinical laboratories. Accordingly, simpler microbiological tests for the detection of MRSA were recommended by the NCCLS $[19,20]$ and were thought to be reliable [21]. In general, addition of $\mathrm{NaCl}$ [23], a cooler incubation temperature $\left(30-35^{\circ} \mathrm{C}\right)$, neutral $\mathrm{pH}$ and prolonged $(48 \mathrm{~h})$ incubation favour detection of MRSA [21]. Several studies have examined the reliability of tests incorporating these factors for the detection of MRSA [16-18], but only one of these discriminated MRSA by class of resistance [14].

The aim of the present study was to investigate whether these tests could reliably discriminate heterogeneous MRSA. Both oxacillin 1- $\mu \mathrm{g}$ disks and MIC determinations by broth macrodilution failed to detect 
Table 1. Behaviour of representative $S$. aureus clinical isolates with different classes of methicillin resistance

\begin{tabular}{|c|c|c|c|c|}
\hline Isolate no. & $\begin{array}{l}\text { Inhibition zone } \\
\text { diameter }(\mathrm{mm})^{*}\end{array}$ & $\begin{array}{l}\text { Growth on methicillin } \\
25 \mathrm{mg} / \mathrm{L} \text { plate } \dagger\end{array}$ & $\begin{array}{c}\mathrm{MIC} \\
(\mathrm{mg} / \mathrm{L}) \ddagger\end{array}$ & Class§ \\
\hline 54 & $8(\mathrm{R})$ & 48 & $1.5-3$ & 1 \\
\hline 69 & 17 (S) & 400 & $1.5-3$ & 1 \\
\hline 79 & $11(\mathrm{R})$ & 1000 & $1.5-3$ & 1 \\
\hline 95 & $8(\mathrm{R})$ & 108 & $1.5-3$ & 1 \\
\hline 97 & 13 (I) & 60 & $1.5-3$ & 1 \\
\hline 96 & $9(\mathrm{R})$ & 62 & $1.5-3$ & 1 \\
\hline 56 & None $(R)$ & C & $12-25$ & 2 \\
\hline 73 & None $(R)$ & $\mathrm{C}$ & $12-25$ & 2 \\
\hline 92 & $8(\mathrm{R})$ & $\mathrm{C}$ & $12-25$ & 2 \\
\hline 99 & $15(\mathrm{~S})$ & 300 & $12-25$ & 2 \\
\hline 47 & None $(\mathrm{R})$ & C & 400 & 3 \\
\hline 52 & None (R) & C & 400 & 3 \\
\hline 55 & None (R) & C & 200 & 3 \\
\hline 56 & None $(\mathrm{R})$ & $\mathrm{C}$ & 200 & 3 \\
\hline 58 & None $(R)$ & $C$ & 800 & 3 \\
\hline 61 & None (R) & $\mathrm{C}$ & 800 & 3 \\
\hline 49 & 12 (I) & None & 2.0 & B \\
\hline 50 & $15(\mathrm{~S})$ & None & 2.0 & B \\
\hline 60 & 19 (S) & None & 2.0 & B \\
\hline 62 & 12 (I) & None & 2.0 & B \\
\hline 63 & $13(\mathrm{~S})$ & None & 2.0 & B \\
\hline 77 & $15(\mathrm{~S})$ & None & 2.0 & B \\
\hline 12 & $10(\mathrm{~S})$ & None & 2.0 & B \\
\hline
\end{tabular}

*The disk diffusion test was according to the NCCLS protocol [19].

† See Materials and methods. Numbers indicate cfu; C, confluent growth on plates after incubation for $18 \mathrm{~h}$ at $37^{\circ} \mathrm{C}$.

¥MIC values and grouping were based upon population analysis profile experiments (Fig. 1) [13]

$\$ 1,2$ and 3, class of methicillin resistance; $\mathrm{B}$, borderline resistance not associated with mecA.

Table 2. Comparison of different screening tests for the detection of MRSA

\begin{tabular}{|c|c|c|c|c|c|c|}
\hline \multirow[b]{3}{*}{ Isolate } & \multirow[b]{3}{*}{ Class } & \multirow{3}{*}{$\begin{array}{l}\text { Growth on agar } \\
\text { with methicillin } \\
25 \mathrm{mg} / \mathrm{L}\end{array}$} & \multicolumn{4}{|c|}{ Growth on screening plates with } \\
\hline & & & \multicolumn{2}{|c|}{ methicillin $10 \mathrm{mg} / \mathrm{L}$} & \multicolumn{2}{|c|}{ oxacillin $6 \mathrm{mg} / \mathrm{L}$} \\
\hline & & & $10^{4 *}$ & $10^{7} \dagger$ & $10^{4 *}$ & $10^{7} \dagger$ \\
\hline 54 & 1 & + & - & - & - & - \\
\hline 69 & 1 & + & - & + & - & + \\
\hline 79 & 1 & + & - & + & - & + \\
\hline 95 & 1 & + & - & + & - & + \\
\hline 96 & 1 & + & - & + & - & + \\
\hline 97 & 1 & + & - & + & - & + \\
\hline 56 & 2 & + & + & + & + & + \\
\hline 73 & 2 & + & + & + & + & + \\
\hline 92 & 2 & + & - & + & - & + \\
\hline 99 & 2 & + & - & + & - & + \\
\hline 49 & B & - & - & - & _ & - \\
\hline 50 & B & - & - & - & - & - \\
\hline 60 & B & - & - & - & - & - \\
\hline 62 & B & - & - & - & - & - \\
\hline 63 & B & - & - & - & - & - \\
\hline 70 & B & - & - & - & - & - \\
\hline 77 & B & - & - & - & - & - \\
\hline
\end{tabular}

*Inoculum of $10^{4} \mathrm{cfu} / \mathrm{plate}$, as recommended by Kloos and Jorgensen [21].

$\dagger$ Inoculum of $10^{7} \mathrm{cfu} /$ plate, as recommended by the NCCLS [19].

c. $30 \%$ of Class 1 and 2 MRSA tested. Moreover, the ranges of inhibition zone diameters of oxacillin $1-\mu \mathrm{g}$ disks for Class 1 and some Class 2 MRSA overlapped those for borderline-resistant strains, confirming previous data [14]. It is unclear why some $m e c A$ negative borderline-resistant $S$. aureus gave zones as small as those for MRSA in diffusion tests. Most of these organisms were $\beta$-lactamase positive and may have hyperproduced this enzyme, especially if it was strongly induced by oxacillin, but this aspect was not investigated.

When broth macrodilution tests in the presence of $\mathrm{NaCl} 2 \% \mathrm{w} / \mathrm{v}$ were used, two of six Class 1 MRSA were not recognised. More reliable results were obtained with screening plates containing oxacillin $6 \mathrm{mg} / \mathrm{L}$ or methicillin $10 \mathrm{mg} / \mathrm{L}$ in the presence of $\mathrm{NaCl} 4 \% \mathrm{w} / \mathrm{V}$ if the NCCLS-recommended inoculum 
of $c .10^{7} \mathrm{cfu} / \mathrm{ml}$ was employed. With these systems, all but one Class 1 MRSA were detected; however, when a less dense inoculum $\left(10^{4} \mathrm{cfu}\right)$ was employed, as recommended by Kloos and Jorgensen [21], only two of 10 Class 1 and 2 isolates were detected as MRSA. Methicillin $25 \mathrm{mg} / \mathrm{L}$ screening plates, employing a very dense inoculum $\left(10^{9}-10^{10} \mathrm{cfu}\right)$, allowed detection of all Class 1 and 2 MRSA. These results demonstrated that inoculum size is critical when screening agar tests are used and that excessively dilute inocula produce false-negative results.

It may seem surprising that the failure of MRSA detection tests to identify heterogeneous Class 1 and 2 isolates has not been remarked upon previously [14]. However, it is possible that few such isolates have been tested; at least in Brazil, recent clinical isolates with Class 1 or 2 behaviour seem to be sporadic [24].

In conclusion, the general reliability of methicillin and oxacillin screening plates for the detection of heterogeneous MRSA clinical isolates was confirmed, although failure of detection still appears to be a risk when testing Class 1 MRSA. For the longer term we recommend that accurate and rapid molecular tests should be developed, but until then, screening plates should be the methods of choice for recognition of MRSA in clinical laboratories.

This work was supported in part by a grant from the Conselho Nacional de Desenvolvimento Científico e Tecnológico ( $\mathrm{CNPq}$ ). A.M.S.F. was the recipient of a fellowship from the Ministerio da Ciência e Tecnologia (RHAE) and C.A.R. was supported by Fundação Aperfeiçoamento de Pessoal do Ensino Superior (CAPES), Brasília, D.F., Brazil. We are very grateful to CECON, São Paulo, SP, Brazil for providing the antibiotic disks.

\section{References}

1. Boyce JM. Increasing prevalence of methicillin-resistant Staphylococcus aureus in the United States. Infect Control Hosp Epidemiol 1990; 11: 639-642.

2. Kerr S, Kerr GE, Mackintosh CA, Marples RR. A survey of methicillin-resistant Staphylococcus aureus affecting patients in England and Wales. $J$ Hosp Infect 1990; 16: 35-48.

3. Marques AR, Petrillo V, Hoefel H. Methicillin-resistant Staphylococcus aureus in a general hospital in Brazil. $J$ Hosp Infect 1989; 14: 380-381.

4. Martin DR, Heffernan HM, Davis HG. Methicillin-resistant Staphylococcus aureus: an increasing threat in New Zealand hospitals. NZ Med $J$ 1989; 102: 367-369.

5. Kayser FH, Wüst J, Santanam P. Genetic and molecular characterisation of resistance determinants in methicillinresistant Staphylococcus aureus. J Med Microbiol 1976; 9: 137-148.

6. Kuhl SA, Pattee PA, Baldwin JN. Chromosomal map location of the methicillin resistance determinant in Staphylococcus aureus. J Bacteriol 1978; 135: 460-465.

7. Hayes MV, Curtiss NAC, Wyke AW, Ward JB. Decreased affinity of a penicillin-binding protein for beta-lactam anti biotics in a clinical isolate of Staphylococcus aureus resistant to methicillin. FEMS Microbiol Lett 1981; 10: 119-122.

8. Hartman BJ, Tomasz A. Expression of methicillin resistance in heterogeneous strains of Staphylococcus aureus. Antimicrob Agents Chemother 1986; 29: 85-92.

9. Hürlimann-Delal RL, Ryffel C, Kayser FH, Berger-Bächi B. Survey of the methicillin resistance-associated genes mecA, $m e c R 1-m e c I$, and femA-femB in clinical isolates of methicillinresistant Staphylococcus aureus. Antimicrob Agents Chemother 1992; 36: 2617-2621.

10. de Lencastre $H$, Tomasz A. Reassessment of the number of auxiliary genes essential for expression of high-level methicillin resistance in Staphylococcus aureus. Antimicrob Agents Chemother 1994; 38: 2590-2598.

11. Tomasz A, Nachman S, Leaf H. Stable classes of phenotypic expression in methicillin resistant clinical isolates of staphylococci. Antimicrob Agents Chemother 1991; 35: 124-129.

12. de Lencastre H, Figueiredo AMS, Tomasz A. Genetic control of population structure in heterogeneous strains of methicillin resistant Staphylococcus aureus. Eur $J$ Clin Microbiol Infect Dis 1993; 12 Suppl 1: S13-S18.

13. Figueiredo AMS, Ha E, Kreiswith $\mathrm{BN}$ et al. In vivo stability of heterogeneous expression classes in clinical isolates of methicillin resistant staphylococci. J Infect Dis 1991; 164: $883-887$.

14. de Lencastre H, Sà Figueiredo AM, Urban K, Rahal J, Tomasz A. Multiple mechanisms of methicillin resistance and improved methods for detection in clinical isolates of Staphylococcus aureus. Antimicrob Agents Chemother 1991; 35: 632-639.

15. Tomasz A, Drugeon HB, de Lencastre HM, Jabes D, McDougall L, Bille J. New mechanism for methicillin resistance in Staphylococcus aureus: clinical isolates that lack the PBP 2a gene and contain normal penicillin-binding proteins with modified penicillin-binding capacity. Antimicrob Agents Chemother 1989; 33: 1869-1874.

16. Archer GL, Pennell E. Detection of methicillin resistance in staphylococci by using a DNA probe. Antimicrob Agents Chemother 1990; 34: 1720-1724.

17. Skulnick M, Simor AE, Gregson D et al. Evaluation of commercial and standard methodology for determination of oxacillin susceptibility in Staphylococcus aureus. $J$ Clin Microbiol 1992; 30: 1985-1988.

18. Tokue Y, Shoji S, Satoh K, Watanabe A, Motomiya M. Comparison of a polymerase chain reaction assay and a conventional microbiological method for detection of methicillin-resistant Staphylococcus aureus. Antimicrob Agents Chemother 1992; 36: 6-9.

19. National Committee for Clinical Laboratory Standards. Performance standards for antimicrobial disk susceptibility tests, 4th edn. Approved standard. M2-A4. National Committee for Clinical Laboratory Standards, Villanova, PA. 1990.

20. National Committee for Clinical Laboratory Standards. Methods for dilution antimicrobial susceptibility tests for bacteria that grow aerobically, 2nd edn. Approved standard. M7-A2. National Committee for Clinical Laboratory Standards, Villanova, PA. 1990.

21. Kloos WE, Jorgensen JH. Staphylococci. In: Balows A, Hausler WJ, Herrmann KL, Isenberg HD, Shadomy HJ (eds) Manual of clinical microbiology, 5th edn. Washington, DC, American Society for Microbiology. 1985: 143-153.

22. Boyce JM. Should we vigorously try to contain and control methicillin-resistant Staphylococcus aureus? Infect Control Hosp Epidemiol 1991; 12: 46-54.

23. Thornsberry C, McDougal LK. Successful use of broth microdilution in susceptibility tests for methicillin-resistant (heteroresistant) staphylococci. J Clin Microbiol 1983; 18: 1084-1091

24. Teixeira LA, Resende CA, Ormonde LR et al. Geographic spread of epidemic multiresistant Staphylococcus aureus clone in Brazil. $J$ Clin Microbiol 1995; 33: 2400-2404. 